Al-Bidayah : jurnal pendidikan dasar Islam

Volume 12, Number 2, December 2020

ISSN: 2549-3388 (online)

Available online at https://jurnal.albidayah.id

Submitted: July 3, 2020, Accepted: December 28, 2020

\title{
ETNOPEDAGOGIC STUDIES IN CHARACTER EDUCATION IN THE MILLENNIAL ERA: CASE STUDY MIN 1 SAMBAS
}

\author{
Purniadi Putra' ${ }^{1}$, Akbar Yuli Setianto ${ }^{2}$, Abdul Hafiz ${ }^{3}$, Mutmainnah ${ }^{4}$, Aslan ${ }^{5}$ \\ Sultan Muhammad Syafiuddin Sambas Islamic Institute, Indonesia ${ }^{1,5}$, MIN 3 \\ Purbalingga, Indonesia ${ }^{2}$, Islamic University of Kalimantan Muhammad Arsyad Al- \\ Banjari Banjarmasin, Indonesia ${ }^{3}$, STAI Al-Haudl Ketapang, Indonesia ${ }^{4}$ \\ E-mail: putrapurniadi@gmail.com ${ }^{1}$, akbaryulisetianto27@gmail.com ${ }^{2}$, \\ abdulhafiz.fsiuniska@gmail.com ${ }^{3}$,imut_machi@yahoo.com ${ }^{4}$, \\ aslanmarani88@yahoo.com ${ }^{5}$
}

DOI: 10.14421/al-bidayah.v12i2.547

\begin{abstract}
The vulnerability of the moral crisis that occurs in millennial children has led to numerous irregularities such as rape, taurine, extortion, bullying and other negative forms of violence. These changes occur due to globalization and the increasing development of technology, thereby leading to deviant behaviours amongst children. Therefore, character education based on ethno pedagogy in Islamic basic education institutions is important due to its ability to reduce the impact of negative behaviours on primary-age children. The purpose of this research is to describe the meaning of ethno pedagogy of MIN 1 Sambas in applying local cultural values. This research uses a naturalistic phenomenology approach through participant observation, interview, and documentation techniques with primary data obtained from students, teachers, parents, and community leaders. The results showed the importance of integrating the self-development program of students based on ethno pedagogy of Melayu Sambas, familiar with fostering character education in creating local cultures such as the Sambas Malay language. Furthermore, ethnology tends to foster a religious character in the millennial generation, namely religious character, such as the attitudes and behaviour of priests and taqwa applied in everyday life.
\end{abstract}

Keywords: ethno pedagogy; character education; millennial era; mi

\section{INTRODUCTION}

The social changes continuously experienced by humans have made Islamic educational institutions, and the general public frequently experiences tremendous challenges, both from outside influences, peers, and technology. The internalization of education at home and school is finally being implemented to enable the proper analysis of social ills in society and schools. Currently, educational institutions are more prone to moral crises, which are carried out by adolescents without considering their age. Some of these incidents include brawls, drug abuse, criminal acts, cases of rape, extortion or violence (bullying), etc. ${ }^{1}$

${ }^{1}$ Erlina Rufaidah, "Revitalisasi Desa Adat Berbasis Pendidikan Dan Kearifan Lokal," Kalam 10, no. 2 (December 30, 2016): 537-54, https://doi.org/10.24042/klm.v10i2.13. Rahmawati Rahmawati, Muh Rusli, and Kasim Yahiji, "Actualization of Local Wisdom in Anticipating Radicalism of Religion In Gorontalo Indonesia,” KALAM 12, no. 2 (2018): 327-52, https://doi.org/10.24042/klm.v12i2.2676. 
The challenges in the world of education are continuously increasing due to the development of the technological era from the agriculture and industrial era. ${ }^{2}$ Presently, the world is in the information age or the change in the generation of ticks to electronics. ${ }^{3}$ The information technology owned by humans today no longer recognizes where people live and their age. ${ }^{4}$ Therefore, the generation born in the 21 st century, otherwise known as the millennial, is dependent on technology, which replaces the position of parents, teachers and community leaders. ${ }^{5}$ The industrial revolution 4.0 not only "shakes" the existence of management education ${ }^{6}$ rather it also challenges the progress of better education in the future. ${ }^{7}$

Teachers tend to lose their existence as educators, ${ }^{8}$ when they envision teaching as pursuing material rather than an act carried out from the heart. Cultural change is not only understood as a transition in negative values, rather it is associated with changes in current cultural values, such as knowledge, behaviour standards, new views of life, and beliefs in society. ${ }^{9}$ Although changes in new cultural values do not affect everything in society, it needs to carry out internalization as a filter for new cultural values. ${ }^{10}$ This filtering of values is inseparable from local wisdom in society which contains values, religious and customary law systems, thereby making it a taboo and prohibited ethics and

${ }^{2}$ Alvin Toffler, Future Shock (New York: Bantam Books, 1970). Alvin Toffler, The Third Wave (New York: William Morrow and Company, INC, 1980), 1-7. 2017).

${ }^{3}$ Mujiburrahman, Agama Generasi Elektronik, Cetakan Pertama (Yogyakarta: Pustaka Pelajar,

${ }^{4}$ Aslan and Hifza, "The Community Of Temajuk Border Education Values Paradigm On The School," International Journal of Humanities, Religion and Social Science 4, no. 1 (2020): 13-20.

${ }^{5}$ Valerie N. Williams et al., "Bridging the Millennial Generation Expectation Gap: Perspectives and Strategies for Physician and Interprofessional Faculty," The American Journal of the Medical Sciences, Symposium: Medical Education and Educators, 353, no. 2 (February 1, 2017): 109-15, https://doi.org/10.1016/j.amjms.2016.12.004.

${ }^{6}$ Katarína Stachová et al., "External Partnerships in Employee Education and Development as the Key to Facing Industry 4.0 Challenges," Sustainability 11, no. 2 (January 2019): 345, https://doi.org/10.3390/su11020345.

${ }^{7}$ Heriyanto Heriyanto et al., "Character Education In The Era Of Industrial Revolution 4.0 And Its Relevance To The High School Learning Transformation Process," Utopía y Praxis Latinoamericana: Revista Internacional de Filosofía Iberoamericana y Teoría Social, no. Extra 5 (2019): 327-40, https://dialnet.unirioja.es/servlet/articulo?codigo=7531750.

${ }^{8}$ Aslan Aslan, "Kurikulum Pendidikan VS Kurikulum Sinetron," Khazanah: Jurnal Studi Islam Dan Humaniora 14, no. 2 (July 9, 2016): 135-48, https://doi.org/10.18592/khazanah.v14i2.1482.

${ }^{9}$ Geneva Gay, Culturally Responsive Teaching: Theory, Research, and Practice (Teachers College Press, 2010), 7.

${ }^{10}$ Peter L Berger, The Sacred Canopy: Elements Of a Sociological Theory Of Religion (Garden City, New York: Doubleday \& Company, Inc, 1967). Peter L. Berger and Thomas Luckhman, The Social Construction Of Reality, vol. 6 (England: Penguin Books, 1991). 
behaviour. ${ }^{11}$ Likewise, socialization in society has shifted from social to asocial feelings. This is due to the many influences of foreign values that enter Indonesian territory without going through the filtering process. Therefore, when this influence is left unchecked, it tends to certainly damage the morale and morals of the younger generation, especially students. ${ }^{12}$

The importance of local culture is re-explored to restore the identity of the Indonesian nation, which is civilized, polite, friendly, and virtuous. It also aims to minimize the current flow of globalization, which is presently getting worse from the low character of today's children. ${ }^{13}$ Ethno pedagogy is a source of innovation and social skill that is generated, stored, managed, and inherited in each respective area. ${ }^{14}$ When social change is increasingly tense in people's lives with surrounding negative values, Ethno pedagogy-based educational institutions serve as an arena to marginalize these negative cultural values. The ethnopedagogical education of the school's goal is to restore students' character in accordance with the characteristics of Melayu Sambas, which is to show a culture of shame that reflects prestige (dignity), an emphasis on honour, reputation, and self-respect rather than guilt. It is also associated with the values of mutual cooperation, consensus, living a simple life, caring for one another, and implementing local pepatih customs. ${ }^{15}$

Mayer \& Cobb $^{16}$ sated that school character education programs play a significant role in teaching self-esteem activities. Most teaching lessons are related to self-esteem, ${ }^{17}$ directly or through related character traits, such as respect, responsibility, self-

${ }^{11}$ Aslan Aslan, "Nilai-Nilai Kearifan Lokal Dalam Budaya Pantang Larang Suku Melayu Sambas," Jurnal Ilmiah Ilmu Ushuluddin 16, no. 1 (July 4, 2017): 11-20, https://doi.org/10.18592/jiu.v16i1.1438.

${ }^{12}$ Binti Maunah, "Implementasi Pendidikan Karakter Dalam Pembentukan Kepribadian Holistik Siswa,” Jurnal Pendidikan Karakter, no. 1 (April 20, 2016), https://doi.org/10.21831/jpk.v0i1.8615.

${ }^{13}$ Purniadi Adi Putra, "Implementasi Pendidikan Karakter: Integrasi Lagu Melayu Sambas Dalam Pembelajaran Pada MIN Kabupaten Sambas,” Sosial Budaya 16, no. 2 (December 22, 2019): 83-92, https://doi.org/10.24014/sb.v16i2.6942.

${ }^{14}$ Nurul Zuriah, "Analisis Teoritik tentang Etnopedagogi Pendidikan Kewarganegaraan sebagai Wahana Pendidikan Budaya dan Karakter Bangsa di Perguruan Tinggi," Sosiohumanika 7, no. 2 (2014), https://doi.org/10.2121/sosiohumanika.v7i2.509.

15 Samsul Susilawati, "Eksistensi Madrasah Dalam Pendidikan Indonesia," Madrasah: Jurnal Pendidikan Dan Pembelajaran Dasar 1, no. 1 (2008), https://doi.org/10.18860/jt.v1i1.1852.

16 Abir Tannir and Anies Al-Hroub, "Effects of Character Education on the Self-Esteem of Intellectually Able and Less Able Elementary Students in Kuwait," International Journal of Special Education 28, no. 2 (2013): 47-59, https://eric.ed.gov/?id=EJ1023237.

17 Leena Holopainen et al., "The Relationship between Students' Self-Esteem, Schoolwork Difficulties and Subjective School Well-Being in Finnish Upper-Secondary Education," International Journal of Educational Research $104 \quad$ (January $1, \quad 2020)$ : 101688 , https://doi.org/10.1016/j.ijer.2020.101688. 
confidence, ${ }^{18}$ self-evaluation, etc. In addition, school counsellors feel it is important to work with student self-esteem because character education is easily overcome from an emotional intelligence perspective.

Educational institutions not only transfer knowledge rather it also teaches culture to students according to their respective regions. ${ }^{19}$ There is a yearly increase in the number of extraordinary cases in Sambas. ${ }^{20}$ According to studies, some heartbreaking events occurred in Sambas community over the last five years, with an increase in the number of sexual violence in minors, which recorded 35, 43, 42 and 14 cases in 2011, 2012, 2013, and 2014, respectively. ${ }^{21}$

Based on the research background above, ethnopedagogical analysis is important due to its ability to reduce the occurrence of character crises in elementary-age children in the millennial era. Therefore, ethnopedagogical education at MIN 1 Sambas is integrating and implementing programs that foster character education through extracurricular activities.

\section{RESEARCH METHODS}

This research method uses a qualitative case study approach. The focus and objectives in this study describe and analyze ethnopedagogical studies in MIN 1 Sambas character education. These include the technique used to implement character education program through Ethno pedagogy in the millennial era and how its implication fosters religious character in the millennial era at Madrasah Ibtidaiyah Negeri 1 Sambas. Primary data such as the physical condition of the madrasah, ceremonies, and rituals, meeting activities, workshops, the atmosphere of the teaching and learning process were obtained from the principal, teachers, madrasah committee, and parents of students. Meanwhile,

${ }^{18}$ Daniela Rupp and Eva Susann Becker, "Situational Fluctuations in Student Teachers' SelfEfficacy and Its Relation to Perceived Teaching Experiences and Cooperating Teachers' Discourse Elements during the Teaching Practicum," Teaching and Teacher Education 99 (March 1, 2021): 103252, https://doi.org/10.1016/j.tate.2020.103252.

${ }^{19}$ Doni Koesoema A, Pendidikan Karakter: Strategi Mendidik Anak di Zaman Global (Jakarta: Grasindo, 2007), h. 8.

${ }^{20}$ Sunandar, "Melayu Dalam Tantangan Globalisasi: Refleksi Sejarah Dan Berubahnya Sistem Referensi Budaya," Khatulistiwa 5, no. 1 (2015): 60-73. Aslan Aslan, "Pendidikan Remaja Dalam Keluarga Di Desa Merabuan, Kalimantan Barat (Perspektif Pendidikan Agama Islam)," Al-Banjari : Jurnal Ilmiah Ilmu-Ilmu Keislaman 16, no. 1 (June 3, 2017): 122-35, https://doi.org/10.18592/albanjari.v16i1.1158.

${ }^{21}$ See http://www.sambas.go.id/home/102-pemerintah-daerah/3105-kasuspemerkosaandan-cabulmeningkat.html (29 Juli 2015). 
secondary data were obtained from books on education, sociology or anthropology, journals, and those relevant to customs and culture in the traditions of the Sambas Malay community in West Kalimantan.

Techniques in data collection include (a) participant observation, through direct technique by actively going to the field to observe the object to be sought, (b) in-depth structured and unstructured interviews carried out for madrasah principals and teachers intending to obtain data in MIN 1 Sambas for the implementation of research to build everyone's thoughts, activities, feelings, and social concerns, as well as (c) documentation technique, which is a technique for obtaining documentative data. These include the history associated with the community's establishment, the management structure, the situation of students and teachers, data on madrasah facilities and infrastructure. Furthermore, data on curriculum, and documentation techniques in this study were collected through notes, archives, and other document sources related to the culture and traditions of the Malay community Sambas.

Data were analyzed by simultaneously utilizing the three stages of the descriptive techniques, in accordance with the research carried out by Miles and Huberman. ${ }^{22}$ These include (a) data reduction, such as grouping, directing, deleting, and organizing, (b) data presentation by determining the characteristics of relationships that have meaning and (c) concluding/verification. Meanwhile, the data validity checking technique is an extension of participation that utilizes attributes other than the checking purposes. $^{23}$

\section{RESULT AND DISCUSSION}

\section{Character Education Program in Ethno Pedagogy MIN 1 Sambas}

Character education programs cultivate spiritual, emotional, intellectual, and selfskills characters in students' daily lives. However, the character education program in Ethno pedagogy aims to foster student character values through an Islamic educational institution, family, and integrated community environment through local culture, both from customs, ways of thinking, acting, religious rituals, and socializing with community members. Several self-development programs in character education were implemented at MIN 1 Sambas, and these include the following.

\footnotetext{
${ }^{22}$ Matthew B. Miles A Michael Huberman, Qualitative Data Analysis: An Expanded Sourcebook (London: SAGE Publication, 1994).

${ }^{23}$ Lexy J. Meleong, Metode Penelitian Kualitatif (Bandung: Remaja Rosdakarya, 2008).
} 


\section{Ethnopedagogical Routine Activities at MIN 1 Sambas}

Through Ethno pedagogy in self-development, the character education program is determined from the daily activities of students before starting their learning process and cleaning the madrasa and class environment. Culture is a human entity that has the following four characteristics, namely (a) interaction between citizens, (b) specific customs, norms, laws, and rules that govern all behaviour patterns of urban or rural citizens, (c) continuity of time, (d) and a strong sense of identity which binds all citizens. This is in accordance with the self-development program accustomed to in madrasas, which is in line with the local Malay culture of Sambas belle '(mutual cooperation), namely the interaction between citizens and customs, the distinctive rules that govern the behaviour patterns of madrasa citizens, and rules of an institution.

The social life of the Malay Sambas community is more characterized by the values of brotherhood in upholding mutual cooperation, consensus living, caring for one another, and instilling the traditional place to live. Therefore, cooperation or belallê is a characteristic of the social associations of the Malay Sambas community. This is consistent with the adage "weight is equivalent to bear, and light equals handing." Furthermore, the culture is always found in the way they work the fields or gardens, carry out marriage ceremonies, obtain blessings, and conduct parties. ${ }^{24}$

According to the interview results carried out with the teacher of MIN 1 Sambas, every Friday, social service activities with the term belle 'clean Friday, is carried out in the environment or classroom on students. This process is carried out to determine students' personal hygiene, such as the cleanliness of clothes, teeth, long nails, and hair. This is always carried out once a week. In addition to routine activities in cleaning the environment with belle, shaping character (refract) is accustomed to "civilized" cultural behavior. Therefore, Budi look basa agrees that the preferred language is refined and polite in madrassas, which friends or relatives use in madrasah as a form of greetings or communication (bilingual or bilateral system).

The Sambas Malay community uses this form of greeting to determine a child's level in the family and the correct form of language for younger siblings or the younger

${ }^{24}$ Endang Susilawati and Asmah Haji Omar, "Makna Sosial Dalam Kata Panggilan: Kajian Etnografi Komunikasi Dalam Komuniti Bahasa Melayu Sambas: Social Meaning In Address Forms: An Ethnographic Study Of Communication In The Sambas Malay Community," Jurnal Pengajian Melayu/Journal of Malay Studies (JOMAS) 28, no. 1 (2017): 85-115, https://ejournal.um.edu.my/index.php/JPM/article/view/9619. 
generation. This is in addition to the greeting for the oldest child, while usu is a form of greeting used by the youngest child. For family members, such as uncle or aunt, the nephew refers to them as "Pak Mude," and every form of along until usu is added with the word "Pak" or "Mak." Grandchildren in a family use the words "Grandma Aki and Grandma Aki" when addressing their grandfather or grandmother. This form indicates that they are descendants of the Sambas community. ${ }^{25}$ Geertz stated that "The social norms associated with kinship, though real, are habitually overridden, even within kinship-type groups themselves, such as families, households, and lineages by culturally better-armed norms associated with religion, politics, and most fundamentally of all, social stratification." 26

The habituated bilingual or bilateral Malay Sambas system aims to shape character education in creating language culture and getting to know more in the Malay Sambas family, which teaches students the habit of not using harsh calls or slang terms commonly heard in the media. Therefore, familiarizing greetings in Sambas Malay culture trains students to form closer ties with the family solidarity.

Habits carried out in accordance with Lickona's opinion stated that there are three ways teachers instil character values in children, namely, (a) kindness, (b) becoming someone that can be imitated by having ethics, respect, and high responsibility, and (c) becoming an ethical guide, ${ }^{27}$ providing moral teaching and guidance. ${ }^{28}$ Therefore, it is important to consider the self-development programs in terms of habituation contained in the teachings of the holy book of Koran to form and practice good behaviour habits. Presently one of the ways to learn through the Koran is by (a) guiding and giving regular exercises and (b) studying the provisions given by God in the presence of a well-regulated universe, the meaning of this learning provides a stimulus for all good and bad deeds to be familiarized with the mind. The self-development program implemented at Madrasah Ibtidaiyah Negeri 1 Sambas has a positive impact, which is instilled from an early age.

${ }^{25}$ Yusriadi, Identitas Orang Melayu di Hulu Sungai Sambas (Pontianak: Elmans’ Institute, 2019). Yusriadi, "Sejarah Dan Perkembangan Orang Melayu Di Riam Panjang, Kalimantan Barat," Khatulistiwa 4, no. 2 (2014): 140-49.

${ }^{26}$ Clifford Geertz, The Interpretation Of Cultures (New York: Basic Books, Inc., Publisher, 1973).

${ }^{27}$ Matthew Davidson et al., "Values Education: The Power2Achieve Approach for Building Sustainability and Enduring Impact," International Journal of Educational Research, Values Education and Holistic Learning, 50, no. 3 (January 1, 2011): 190-97, https://doi.org/10.1016/j.ijer.2011.07.006.

${ }^{28}$ Thomas Lickona, Educating For Character: Mendidik Untuk Membentuk Karakter, Terj. Juma Abdu Wamaungo (Jakarta: Bumi Aksara, 2012). 
When the self-development program is actualized, students feel happy and no longer find it difficult with the habit of living in the environment of everyday life. Kearifan lokal memiliki ciri khusus dalam penerapannya. The following are characteristics of local wisdom, (a) it needs to combine with the wisdom of knowledge that teaches people ethics and moral values, (b) it needs to educate people to love and not destroy nature, and (c) local wisdom needs to come from older members of the community. ${ }^{29}$

\section{Ethno Pedagogy Extracurricular Program MIN 1 Sambas}

The extracurricular program is applied regularly and programmatically in the madrasah local content curriculum. There are various activities in the extracurricular program associated with the approaches and methods in fostering student character until they become grown-ups. In this case, when it is related to the challenges of the Millennial era, strategies in the context of divine value education are strategies that use programs in making religious education in order to create a religious climate capable of fostering divine values. Meanwhile, the concept of behaving valuable in the perspective of God has a relationship with divine values, and in a broad sense, it views religion as valuable. ${ }^{30}$ Madrasah Ibtidaiyah Negeri 1 Sambas extracurricular activities comprise sports, arts, Scouts, PMR, and UKS support in fostering student character education. Asides from that, students' religious activities in participating in the TPA program make them engage in extracurricular activities after school.

The activity of TPA MIN 1 Sambas aims to form an IMTAQ attitude in knowing the meaning of worship such as prayer, reading the Qur'an, respecting elders, and obtaining achievements in competitions. Some of the material provided include (1) micro ', al-Qur'an, short chapters of the Koran, religious knowledge, and congregational prayer, (2) all students become participants in both grades I-VI, (3) all technical processes are carried out individually and classically, (4) funding from infaq students, (5) discipline, (6) presence books (7) media: Iqro ', (al-Qur'an). Al-Qur'an is a guide to prepare for the afterlife. The findings of the tutor of the head of the TPA at MIN 1 Sambas stated that "kite orang Melayu Sambas from the heritage of urang ge'mare kite (an ancient person)

${ }^{29}$ Riga Zahara Nurani and Hatma Heris Mahendra, "Implementation Of Character Education Strengthening Based On Local Wisdom In Sd Laboratorium Upi Tasikmalaya," PrimaryEdu - Journal of Primary Education 4, no. 1 (February 19, 2020): 28, https://doi.org/10.22460/pej.v4i1.1596.

${ }^{30}$ Kamrani Buseri, Dasar, Asas Dan Prinsip Pendidikan Islam (Banjarmasin: IAIN Antasari, 2014). 
has been taught to be customary Islam with syara', based on Kitabullah which means someone from Malay with a religion. Everyday Islam speaks Malay with its customs."

In addition, from the results of the interview, the Head of MIN 1 Sambas revealed that " extracurricular activities in the field of children's art practice, such as the raddat, zapin, and manggar dances, are prepared for regency level competitions even at the provincial level, apart from the traditional Malay Sambas song.

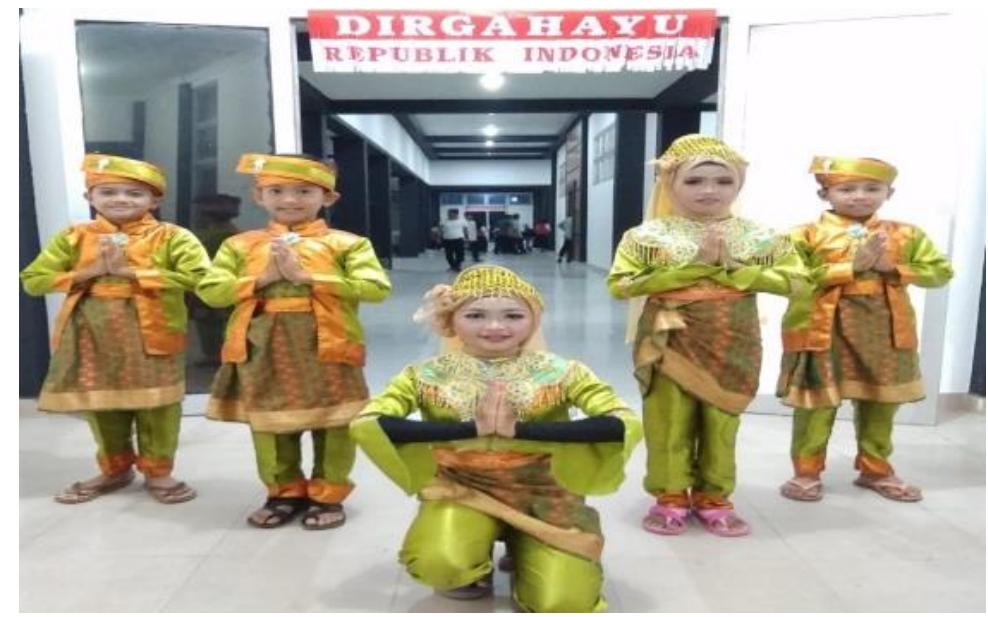

Figure 1

Malay Sambas Dance Performance at the Sambas Regent's Office

The extracurricular program held at MIN 1 Sambas, has been implemented for a long time. According to one of the coordinators and coaches, "The program was implemented almost three years ago, and the penance is from grade 5 to 6 . The dancers are trained in traditional Malay Sambas with a combination of the sengalauwan tappor dance, although this is dependent on the cultural conditions of the area. The Sambas Malay dance explores the culture and forms character values in students with numerous philosophical characteristics. Sengalawan Tappor eye dance is from the Sambas area and performed by students of MIN 1Sambas.

Every extracurricular program created by MIN 1 Sambas is in accordance with the vision, mission and program objectives made by Lickona's opinion. The extracurricular program is the most effective means of helping students foster a sense of value as humans in their school. There are several benefits of extracurricular programs, including TPA activities given to children to increase their aesthetic character and creative power value. Scout education, which produces character values for students that 
are creative, dynamic, love the natural environment, and are full of discipline. Sports are useful for maintaining health and obtaining a clean and healthy behaviour.

Research reinforces this carried out by Lickona, which stated that academic learning increases when the following are achieved. (a) Character education programs from schools improve the quality of human relations in enhancing the environment for teaching and learning, and (b) efforts to improve character education are found in strong academic programs in teaching skills to students and hard work habits. ${ }^{31}$

\section{Implications of Character Education in Ethno Pedagogy of MIN 1 Sambas in the Millennial Era}

The ethnopedagogical implication of character education in this millennial era is in accordance with the vision and mission of the madrasa to improve noble morals based on the al-Qur'an and Hadith. Various programs and approaches are made with the Sambas Malay Ethno pedagogy elements to shape students' religious (Islamic) attitudes and behaviour. The function of formal institutions in shaping character education for religious character plays an essential role as a follow-up from parents at home. Religious activities made in madrasas make students display religious character both in madrasas, families, and communities. This is reinforced by a statement by Pak Wiyono, a principal who revealed that character education program based on local culture strengthen students' love for local culture. ${ }^{32}$ Furthermore, one of the class teachers, named Ibu Suryati, stated that "facilities also provide support for the creation of character education that is always cultured." ${ }^{33}$ In the context of this research, the ethnopedagogical implications of the millennial era at MIN Sambas have actually succeeded in fostering religious attitudes and behaviours of students, especially in terms of hablum minallah, by making them religious, while applying the attitude and behaviour of Imam and taqwa in everyday life.

Ramayulis, ${ }^{34}$ stated that religious attitude is an overall interaction between knowledge, feelings, and actions within a person. With these attributes, religious behaviour is born in accordance with the level of one's obedience and belief. There are

31 Thomas Lickona, Character Matters: How to Help Our Children Develop Good Judgment, Integrity, and Other Essential Virtues (New York: Simon and Schuster, 2004).

32 Wiyono, Interview with Principal at MIN 1 Sambas About the Character Education Implementation Program, 2019.

${ }^{33}$ Suryani, Interview with classroom teachers at MIN 1 Sambas about supporting facilities, 2019.

${ }^{34}$ Ramayulis, Psikologi Agama (Jakarta: Kalam Mulia, 2007). 
several historical facts about the Sambas Malay community during the Sultanate / Kingdom, which are known to be very religious in West Kalimantan and also known as "Serambi Makkah." In the Sambas kingdom, Islamic scholars from the Sultanate of Sambas were very prominent, and some had international calibre. ${ }^{35}$ The influence of the role of parents and teachers in shaping religious attitudes and behaviour in children is very important. Psychological guidance is directed at forming religious values, meanwhile exemplary, habituation, and discipline focused on charity. Both have a reciprocal relationship with religious awareness and experience shaped through an integrated mentoring process. The expected result is to become a human figure that believes in religious awareness and does good deeds. ${ }^{36}$

The role of teachers and parents in shaping students into figures of faith and piety in everyday life is indeed a shared responsibility. The development of students at this basic level is related to the provision of religious material and developing understanding and providing training or habituation. The religion associated with worship, such as praying and reading the Koran, need to be accustomed to memorizing short surahs and their translations. In addition to getting used to worship, it is also accustomed to conducting social worship related to fellow humans.

Zakiah Daradjat, ${ }^{37}$ stated that religious education in elementary schools is the basis for fostering positive attitudes towards religion and successfully shaping the personality and morals of children. Therefore, to develop this attitude, adolescents are easy, and children have guidelines or provisions in dealing with various shocks that usually occur during this period. According to Ramayulis, ${ }^{38}$ an understanding of the concept of religion in children means having proper knowledge of nature in them. In accordance with their characteristics, the nature of religion in children grows according to the pattern of "ideas concept on authority." Religious ideas in children are almost entirely authoritative, meaning that external elements influence the concepts.

Based on the research on religious behaviour at MIN, it is important to note that religious behavior is obtained from the spiritual aspect rather than the physical. This is seen from obeying applicable regulations, such as having responsibility. While from the

${ }^{35}$ Rizal Muntansyir, Kearifan Lokal Masyarakat Melayu Dalam Tinjauan Filosofis, Legenda Rakyat, Filosofis Air, Dan Tradisi (Yogyakarta: Fakultas Filsafat, Universitas Gadjah Mada, 2016), h. 27.

${ }^{36}$ Jalaludin, Psikologi Agama (Jakarta: PT. Remaja Rosdakarya, 2002).

${ }^{37}$ Zakiah Daradjat, Metodologi Pengajaran Agama Islam (Jakarta: Bumi Aksara, 2008).

${ }^{38}$ Ramayulis, Psikologi Agama. 
spiritual, religious aspect, students are accustomed to carrying out worship such as praying at noon in a congregation, participating in TPA activities, and memorizing juz amma. The ethnopedagogical implication of religious character in facing the millennial era at MIN 1 Sambas provides intended religious programs and collaborates with families, communities, and the government. One of the collaborative programs with the community and family is to appoint a religious leader (labia) to teach the Al-Quran to children every evening to guide their daily lives.

Abdul Majid and Dian Andayani, stated that belief is an attitude in the heart associated with believing in Allah and placing trust in Him. Meanwhile, Ulwan stated that expressing piety is the final value and the fruit of character from a deep feeling of faith connected with the fear of being watched over by Allah and being greedy for His forgiveness and reward. ${ }^{39}$

\section{CONCLUSION}

In conclusion, the study of ethnopedagogy in developing students' character at the basic education level is very important because this age is the foundation for the formation of attitudes and behaviour associated with a region. Therefore, ethnopedagogy in madrasah strengthens character and the ability to ward off negative things in this millennial era. With the existence of ethnopedagogy in character education, it is important to offset the negative effects of capitalism and the flow of globalization in this millennial era. The MIN 1 Sambas program, which has the nuances of local wisdom of Melayu Sambas, significantly contributes to students' religious attitudes and behaviour. For instance, it ensures that students know their local culture with the desire to build their region. In addition, ethnopedagogy in the learning process is likely to remain sustainable because it is implemented in concrete everyday life as school culture. The recommendation in this study is that the local content curriculum is held again at school or madrasah educational institutions that already have a local content curriculum. Therefore, teachers need to also become millennial without eliminating the distinctive characteristics of local wisdom to instil the right values in children according to the needs of the times. Character education with the presence of local culture (ethnopedagogy)

${ }^{39}$ Abdulah Nashih Ulwan, Pendidikan Anak dalam Islam yang Komprehensif: Menyambut Belahan Jiwa Yang Islami (Dilariza, 2019). 
contributes to the habits of students in daily life, which are integrated into the culture of the Sambas community.

\section{REFERENCES}

Aslan, Aslan. "Kurikulum Pendidikan VS Kurikulum Sinetron." Khazanah: Jurnal Studi Islam Dan Humaniora 14, no. 2 (July 9, 2016): 135-48. https://doi.org/10.18592/khazanah.v14i2.1482.

Aslan, Aslan. "Nilai-Nilai Kearifan Lokal Dalam Budaya Pantang Larang Suku Melayu Sambas." Jurnal Ilmiah Ilmu Ushuluddin 16, no. 1 (July 4, 2017): 11-20. https://doi.org/10.18592/jiu.v16i1.1438.

Aslan, Aslan. "Pendidikan Remaja Dalam Keluarga Di Desa Merabuan, Kalimantan Barat (Perspektif Pendidikan Agama Islam)." Al-Banjari : Jurnal Ilmiah IlmuIlmu Keislaman 16, no. 1 (June 3, 2017): 122-35. https://doi.org/10.18592/albanjari.v16i1.1158.

Aslan and Hifza. "The Community Of Temajuk Border Education Values Paradigm On The School." International Journal of Humanities, Religion and Social Science 4, no. 1 (2020): 13-20.

Berger, Peter L. The Sacred Canopy: Elements Of a Sociological Theory Of Religion. Garden City, New York: Doubleday \& Company, Inc, 1967.

Buseri, Kamrani. Dasar, Asas Dan Prinsip Pendidikan Islam. Banjarmasin: IAIN Antasari, 2014.

Daradjat, Zakiah. Metodologi Pengajaran Agama Islam. Jakarta: Bumi Aksara, 2008.

Davidson, Matthew, Vladimir Khmelkov, Kyle Baker, and Thomas Lickona. "Values Education: The Power2Achieve Approach for Building Sustainability and Enduring Impact." International Journal of Educational Research, Values Education and Holistic Learning, 50, no. 3 (January 1, 2011): 190-97. https://doi.org/10.1016/j.ijer.2011.07.006.

Doni A, Koesoema. Pendidikan Karakter: Strategi Mendidik Anak di Zaman Global. Jakarta: Grasindo, 2007.

Gay, Geneva. Culturally Responsive Teaching: Theory, Research, and Practice. Teachers College Press, 2010.

Geertz, Clifford. The Interpretation Of Cultures. New York: Basic Books, Inc., Publisher, 1973.

Heriyanto, Heriyanto, A. Komariah, D. Satori, and A. Suryana. "Character Education In The Era Of Industrial Revolution 4.0 And Its Relevance To The High School Learning Transformation Process." Utopía y Praxis Latinoamericana: Revista Internacional de Filosofía Iberoamericana y Teoría Social, no. Extra 5 (2019): 327-40. https://dialnet.unirioja.es/servlet/articulo?codigo=7531750.

Holopainen, Leena, Katariina Waltzer, Nhi Hoang, and Kristiina Lappalainen. "The Relationship between Students' Self-Esteem, Schoolwork Difficulties and Subjective School Well-Being in Finnish Upper-Secondary Education." 
International Journal of Educational Research 104 (January 1, 2020): 101688. https://doi.org/10.1016/j.ijer.2020.101688.

Jalaludin. Psikologi Agama. Jakarta: PT. Remaja Rosdakarya, 2002.

Lickona, Thomas. Character Matters: How to Help Our Children Develop Good Judgment, Integrity, and Other Essential Virtues. New York: Simon and Schuster, 2004.

Lickona, Thomas. Educating For Character: Mendidik Untuk Membentuk Karakter, Terj. Juma Abdu Wamaungo. Jakarta: Bumi Aksara, 2012.

Matthew B. Miles A Michael Huberman. Qualitative Data Analysis: An Expanded Sourcebook. London: SAGE Publication, 1994.

Maunah, Binti. "Implementasi Pendidikan Karakter Dalam Pembentukan Kepribadian Holistik Siswa." Jurnal Pendidikan Karakter, no. 1 (April 20, 2016). https://doi.org/10.21831/jpk.v0i1.8615.

Meleong, Lexy J. Metode Penelitian Kualitatif. Bandung: Remaja Rosdakarya, 2008.

Mujiburrahman. Agama Generasi Elektronik. Cetakan Pertama. Yogyakarta: Pustaka Pelajar, 2017.

Muntansyir, Rizal. Kearifan Lokal Masyarakat Melayu Dalam Tinjauan Filosofis, Legenda Rakyat, Filosofis Air, Dan Tradisi. Yogyakarta: Fakultas Filsafat, Universitas Gadjah Mada, 2016.

Nurani, Riga Zahara, and Hatma Heris Mahendra. "Implementation Of Character Education Strengthening Based On Local Wisdom In Sd Laboratorium Upi Tasikmalaya." PrimaryEdu - Journal of Primary Education 4, no. 1 (February 19, 2020): 28. https://doi.org/10.22460/pej.v4i1.1596.

Peter L. Berger and Thomas Luckhman. The Social Construction Of Reality. Vol. 6. England: Penguin Books, 1991.

Putra, Purniadi Adi. "Implementasi Pendidikan Karakter: Integrasi Lagu Melayu Sambas Dalam Pembelajaran Pada MIN Kabupaten Sambas.” Sosial Budaya 16, no. 2 (December 22, 2019): 83-92. https://doi.org/10.24014/sb.v16i2.6942.

Rahmawati, Rahmawati, Muh Rusli, and Kasim Yahiji. "Actualization of Local Wisdom in Anticipating Radicalism of Religion In Gorontalo Indonesia." KALAM 12, no. 2 (2018): 327-52. https://doi.org/10.24042/klm.v12i2.2676.

Ramayulis. Psikologi Agama. Jakarta: Kalam Mulia, 2007.

Rufaidah, Erlina. "Revitalisasi Desa Adat Berbasis Pendidikan Dan Kearifan Lokal." Kalam 10, no. 2 (December 30, 2016): 537-54. https://doi.org/10.24042/klm.v10i2.13.

Rupp, Daniela, and Eva Susann Becker. "Situational Fluctuations in Student Teachers' Self-Efficacy and Its Relation to Perceived Teaching Experiences and Cooperating Teachers' Discourse Elements during the Teaching Practicum." Teaching and Teacher Education 99 (March 1, 2021): 103252. https://doi.org/10.1016/j.tate.2020.103252. 
Stachová, Katarína, Ján Papula, Zdenko Stacho, and Lucia Kohnová. "External Partnerships in Employee Education and Development as the Key to Facing Industry 4.0 Challenges." Sustainability 11, no. 2 (January 2019): 345. https://doi.org/10.3390/su11020345.

Sunandar. "Melayu Dalam Tantangan Globalisasi: Refleksi Sejarah Dan Berubahnya Sistem Referensi Budaya." Khatulistiwa 5, no. 1 (2015): 60-73.

Susilawati, Endang, and Asmah Haji Omar. "Makna Sosial Dalam Kata Panggilan: Kajian Etnografi Komunikasi Dalam Komuniti Bahasa Melayu Sambas: Social Meaning In Address Forms: An Ethnographic Study Of Communication In The Sambas Malay Community." Jurnal Pengajian Melayu/Journal of Malay Studies (JOMAS) 28, no. 1 (2017): https://ejournal.um.edu.my/index.php/JPM/article/view/9619.

Susilawati, Samsul. "Eksistensi Madrasah Dalam Pendidikan Indonesia." Madrasah: Jurnal Pendidikan Dan Pembelajaran Dasar 1, no. 1 (2008). https://doi.org/10.18860/jt.v1i1.1852.

Tannir, Abir, and Anies Al-Hroub. "Effects of Character Education on the Self-Esteem of Intellectually Able and Less Able Elementary Students in Kuwait." International Journal of Special Education 28, no. 2 (2013): 47-59. https://eric.ed.gov/?id=EJ1023237.

Toffler, Alvin. Future Shock. New York: Bantam Books, 1970.

- The Third Wave. New York: William Morrow and Company, INC, 1980.

Ulwan, Abdulah Nashih. Pendidikan Anak dalam Islam yang Komprehensif: Menyambut belahan jiwa yang islami. Dilariza, 2019.

Williams, Valerie N., Jose Medina, Andria Medina, and Shari Clifton. "Bridging the Millennial Generation Expectation Gap: Perspectives and Strategies for Physician and Interprofessional Faculty." The American Journal of the Medical Sciences, Symposium: Medical Education and Educators, 353, no. 2 (February 1, 2017): 109-15. https://doi.org/10.1016/j.amjms.2016.12.004.

Yusriadi. Identitas Orang Melayu di Hulu Sungai Sambas. Pontianak: Elmans' Institute, 2019.

—. "Sejarah Dan Perkembangan Orang Melayu Di Riam Panjang, Kalimantan Barat." Khatulistiwa 4, no. 2 (2014): 140-49.

Zuriah, Nurul. "Analisis Teoritik tentang Etnopedagogi Pendidikan Kewarganegaraan sebagai Wahana Pendidikan Budaya dan Karakter Bangsa di Perguruan Tinggi." Sosiohumanika 7, no. 2 (2014). https://doi.org/10.2121/sosiohumanika.v7i2.509. 
This page is intentionally left blank 